\title{
Editorial
}

\section{Jan Hendrik Stock \\ 22 February 1931 - 17 February 1997}

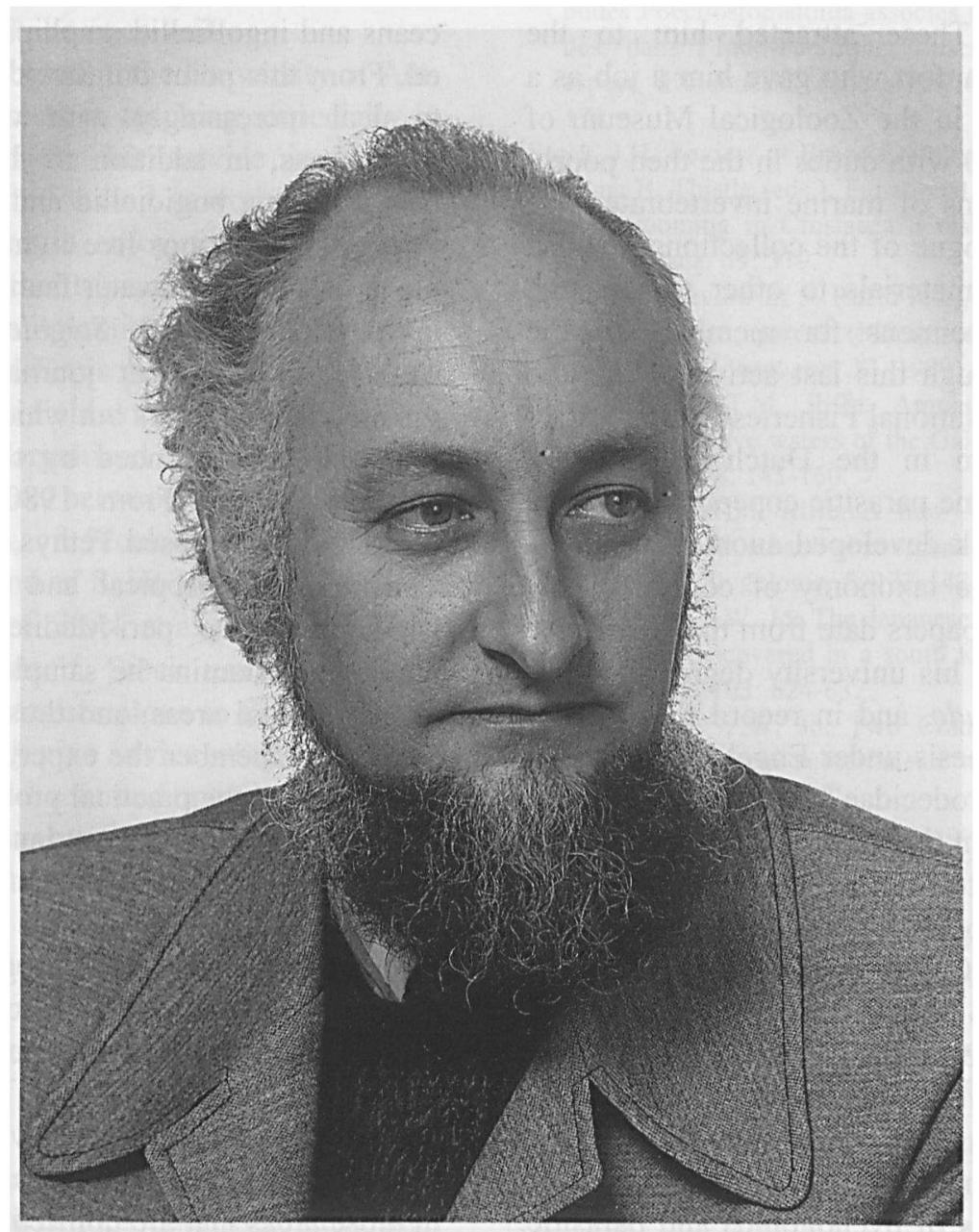

Jan H. Stock in 1974 (Photo: Louis van der Laan)

Jan Stock was born in western Amsterdam 22 February 1931, the only child of Jan Hendrik Stock, a bank clerk, and Elisabeth Stock-Knevel. $\mathrm{He}$ exhibited an early interest as a child in living things, raising plants on a back balcony of his parents apartment and collecting animals during family excursions to the beaches at Zandvoort. However, it was in his early teens in the Hoogere
Burgerschool that his interest in biology blossomed where he achieved perfect scores in natural history on his final examinations. He entered the University of Amsterdam in 1948 to pursue his studies of biology and worked under such figures as Profs. L.F. de Beaufort and H. Engel - his predecessors in the chair of Special Zoology - as well as Profs. J.E.W. Ihle and E.J. Slijper. It was 
Ihle in fact who first encouraged Stock to take up the study of pycnogonids, the sea spiders, a group in which he made some of his initial scientific contributions.

His first scientific articles date from the student years and appeared in Het Zeepaard, the journal of the beach research groups of the Dutch YouthUnion for Nature Studies and the Dutch Natural History Society. These attracted him to the attention of De Beaufort who gave him a job as a curatorial assistant in the Zoological Museum of Amsterdam in 1950 with duties in the then poorly organized collections of marine invertebrates. He set up a card catalogue of the collections, tracked loans of museum materials to other researchers, and identified specimens for members of the public. It was through this last activity, when he received from the National Fisheries Institute (then at Bergen-op-Zoom in the Dutch province of Noord-Brabant) some parasitic copepods afflicting mollusks, that Stock developed another of his research interests, the taxonomy of copepods. His first real scientific papers date from that year.

Stock completed his university degree in 1955 , graduating cum laude, and in record time he defended his Ph.D. thesis under Engel, "The pycnogonid family Austrodecidae", in 1957. The comments solicited from three foreign members of his examining committee, Isabella Gordon of the British Museum, Joel Hedgpeth of the old Pacific Marine Station in California, and Ernst Mayr of Harvard, helped to insure that Stock received a cum laude for that effort as well.

For the next 11 years, as curator of Crustacea at the Zoological Museum of Amsterdam, he produced a massive amount of research work, most of it in the systematics of pycnogonids and parasitic copepods, much of the latter in French dealing with the parasitic forms from the coasts of France. Stock's first publications concerning gammarid amphipods, for which he was so well known later, appeared as early as 1952; his interests and publications soon ranged across the Eurasian landmass from Holland to Lake Baikal.

He married Brenda Balfoort in 1964 and they had four sons. In 1968, with the retirement of Engel, Stock succeeded to the chair. Among his duties as professor was to act as editor of this journal (then known by its Dutch name as Bijdragen tot de Dierkunde). He was also instrumental in establishing the Bulletin Zoölogisch Museum Universiteit van Amsterdam for the publication of purely taxonomic studies. It was about this time that his full fledged interest in groundwater faunas began to develop, although it was not until 1976 that his initial scientific publications, in thermosbaenaceans and ingolfiellid amphipods, actually appeared. From this point on, Stock's publications came to deal increasingly with various groundwater crustaceans, in addition to those just mentioned also including bogidiellid and hadziid amphipods, isopods, and various free-living copepods. Indeed, his work on groundwater faunas led to his helping to found the joumal Stygologia, which quickly became an important journal in the field and remained so for years but which unfortunately was eventually discontinued by the publisher for financial reasons. From 1980 onward, he concentrated on supposed Tethys derived biotas in the Caribbean, the tropical and subtropical Atlantic islands and the peri-Mediterranean belt. With unrelenting stamina he sampled these islands and nearby coastal areas, and those who accompanied him will remember the experienced way in which he tackled all the practical problems - from getting permits from suspicious land-owners to giving lectures in every conceivable circumstance. From his extensive collections he extracted a general theory, which he called the Regression Model. This is an essentially vicariant scenario that tries to explain and predict how several Tethyan, marine ancestors became adapted to groundwater conditions during periods of relative low sea level, and how these descendants are found and will be found in those areas that are uplifted.

By the time he retired in October 1990, Jan Stock had published some 462 articles. Freed of his academic responsibilities, retirement only increased his productivity. At the time of his death he had published more than 76 additional papers, and several items are now in press or ready to be submitted - a truly astounding level of productivity of around 14 papers per year.

An intensely private man, he good naturedly erected a screen of fabulous stories around his life. For example, one of us (FRS) quite believed that 
Stock was born in the Dutch East Indies because Jan had most convincingly told him so many years ago, and it was'only in preparing this obituary that he was surprised to learn that Stock was born right in Amsterdam. Stock's humor was legendary and he revelled in regaling students and colleagues with some of the most elaborate and tongue-incheek tales. "A good story is a good story, no matter if it is true or not", he once said.

He will be remembered in the University of Amsterdam for his interests in teaching, especially in field situations, and for his service in biology faculty administration, having served as dean for some years. His intense enjoyment of fieldwork resulted in, among other trips, major expeditions to the Red Sea, various Atlantic Islands, and participation in the Dollard-Eems project in the Wadden Sea. This devotion to fieldwork continued after his retirement, and he organized another two major expeditions in the years between his retirement and death (to St. Helena, cf. Stock, 1995 "Origin and evolution of the island of Saint-Helena" and to the Sultanate of Oman, cf. Stock et al., 1997).

A workaholic himself, Stock nevertheless left his students and colleagues alone to find their own way. He would gladly give advice when asked, and he promptly read and returned manuscripts when they were given to him. However, he firmly believed that everyone should find their own level of productivity. Jan Stock will be greatly missed around the Zoological Museum of Amsterdam, but his scientific work in the systematics of marine arthropods is an enduring monument.

A bibliography of Jan Stock up to 1990 can be found in Weinberg \& van Zijl (1990, Bulletin Zoölogisch Museum, Special Issue 1990: 1-42) and an update of his publications published since then is included here.

Frederick R. Schram

Ronald Vonk

\section{Additional publications of J.H. Stock}

1990

Stock, J.H. Sur deux Pycnogonides armoricains remarquables. Cah. Biol. mar., 31: 513-516.
Stock, J.H. Insular groundwater biotas in the (sub)tropical Aflantic: A biogeographic synthesis. Atti Conv. Accad. Naz. Lincei (Roma), 85: 695-713.

Stock, J.H. A new forest-hopper (Amphipoda, Talitridae) from La Palma, Canary Islands. Vieraea, 18: 91-98.

Stock, J.H. A new species of Austrodecus (Pycnogonida) from New South Wales, Australia. Tijdschr. Entom., 133: 269-272.

Stock, J.H. Présence de la famille des Serpulicolidae, Copépodes Poecilostomatoida associés aux Polychètes Serpulidés, dans l'Indo-Pacifique: Description d'une nouvelle espèce d"Indonésie. Indo-Malay. Zool., 6 (1989): 165171.

Stock, J.H. Review of Bruce E. Felgenhauer, Les Watling \& Anne B. Thistle (eds.), Functional morphology of feeding and grooming in Crustacea. Crustacean Issues, 6, 1989. Crustaceana, 59: 319.

Stock, J.H. Review of S. Ruffo (ed.), The Amphipoda of the Mediterranean, part 2 (Mémoires de I'Institut Océanographique, Monaco, no. 13, 1989). Crustaceana, 59: 319.

Stock J.H. \& T.M. Iliffe. Amphipod crustaceans from

- anchihaline cave waters of the Galapagos Islands. Zool. J. Linn. Soc., 98: 141-160.

Stock J.H. \& T.M. Iliffe. A new Australian crangonyctid amphipod with a habit convergent to the Old World genus Niphargus. Stygologia, 5: 137-142.

Stock J.H. \& Y.W. Jo. The Japanese amphipod genus Eoniphargus rediscovered in a south Korean cave. Proc. biol. Soc. Wash., 103: 624-632.

Stock, J.H. \& Y.W. Jo. Two Crangonyetidae (Crustacea, Amphipoda) from subterranean waters of the Far East. Stygologia, 5: 119-127.

Stock, J.H. \& E. Sánchez. First record of Crustacea Malacostraca from fresh waters in the Canary Islands. Hydrobiologia, 206: 53-59.

Stock, J.H. \& R. Vonk. A freshwater amphipod from La Gomera, Melita dulcicola n. sp. (Stygofauna of the Canary Islands, 23). Annls. Limnol., 26: 29-37.

Stock, J.H. \& R. Vonk. Marine interstitial Isopoda Asellota of the superfamily Gnathostenetroidoidea. Cah. Biol. mar., 31: 5-24.

Pretus J.L. \& J.H. Stock. A new hyporheic Bogidiella (Crustacea, Amphipoda) from Mallorca. Endins, 16: 47-51.

Stock, J.H. Deep-water Pycnogonida from the surroundings of New Caledonia. In: A. Crosnier (ed.), Résultats des Campagnes MUSORSTOM, 8. Mém. Mus. natn. Hist. nat., (A) 151: 125-212.

Stock, J.H. A new species of Psammogammarus (Amphipoda, Melitidae) from river alluvia in Luzon, Philippines. Stygologia, 6: 227-233.

Stock, J.H. Pycnogonida of the MUSORSTOM campaigns to the Philippines. In: A. Crosnier (ed.), Résultats des Campagnes MUSORSTOM, 8. Mém. Mus. natn. Híst. nat. (A) 151: 213-228. 
Stock, J.H. Pycnogonides de la campagne Seamount 1 au large de la péninsule ibérique et dans le golfe ibéro-marocain. Bull. Mus. natn. Hist. nat., Paris, (4) 13 (A): 135142 .

Stock, J.H. Some reflections on the antiquity of the copepod lineages. Proc. Fourth Int. Conf. Copepoda; Bull. Plankton Soc. Japan, Spec. Vol. (1991): 1-7.

Stock, J.H. \& T.M. Iliffe. Two new species of Liagoceradocus (hypogean Amphipoda) from south-western Pacific Islands, with key to the world species. Invertebr. Taxon., 5: 807-825.

Stock, J.H. \& D. Platvoet. The freshwater Amphipoda of the Falkland Islands. J. nat. Hist., 25: 1469-1491.

Stock, J.H. \& R. Vonk. Une espèce nouvelle de Dulzura, genre d'Amphipodes hadzioīdes connu jusqu'ici seulement de l'Indo-Pacifique, découverte aux îles du CapVert (Océan Atlantique). Cah. Biol, mar., 32: 477-486.

Humes, A.G. \& J.H. Stock. Coralliomyzontidae, fam. n. (Copepoda: Siphonostomatoida) associated with scleractinian corals in Madagascar. Bull, zoöl. Mus. Univv. Amsterdam, 13: 17-24.

Pretus, J.L. \& J.H. Stock. A new hyporheic Bogidiella (Crustacea, Amphìpoda) from Mallorca. Endins, 16: 47-51.

Vonk, R. \& J.H. Stock. Caecostenetroides ascensionis n. sp., a blind marine interstitial isopod (Asellota, Gnathostenetroidoidea) from Ascension Island, South Atlantic. Trop. Zool., 4: 89-98.

\section{2}

Stock, J.H. Bogidiella (Amphípoda) in Japanese inland waters. Crustaceana, 62: 273-282.

Stock, J.H. Discovery of the male and subgeneric status of Bogidiella cypria Karaman, 1989 (Crustacea, Amphipoda). Stygologia, 7: 117-118.

Stock, J.H. Entomolepididae (Copepoda, Siphonostomatoida) from the Antilles. Stud. nat. Hist. Caribb. Region, 71: 5368.

Stock, J.H. Littoral Pycnogonida from Oman. Bijdr. Dierk., 62: 81-98.

Stock, J.H. A new species of Hemicyclops (Crustacea, Copepoda, Poecilostomatoida, Clausidiidae) associated with hermit crabs in Curacao. Stud. nat. Hist. Caribb. Region, 71: 69-78.

Stock, J.H. A new species of Ingolfiella (Crustacea, Amphipoda, Ingolfiellidea) from mixohaline waters in Madeira. Bocagiana, 159: 1-11.

Stock, J.H. Pycnogonida from southern Brazil. Tijdschr. Ent., 135: 113-139.

Stock, J.H. Shifting ranges and biodiversity in animal ecosystems. In: O.T. Solbrig, H.M. van Emden \& P.G.W.J. van Oordt (eds), Biodiversity and global change. Int. Union biol. Sci., Monogr. 8: 167-171.

Stock, J.H. \& R. Vonk. The first freshwater amphipod (Crustacea) from the Cape Verde Islands: Melita cognata n. sp., with notes on its evolutionary scenario. Revue Zool. Afr., 106: 273-280.
Stock, J.H. \& R. Vonk. Marine interstitial Amphipoda and Isopoda (Crustacea) from Santiago, Cape Verde Islands. Bijdr. Dierk., 62: 21-36.

\section{3}

Stock, J.H. Adenaplostoma monniotorum n. gen., n. sp., . a strange copepod parasite of a compound ascidian from New Caledonia (Crustacea, Copepoda, Cyclopoida, Ascidicolidae). Bull. Mus. natn. Hist. nat., Paris, (4) 15 (A): 117-123.

Stock, J.H. Biogeography and evolutionary scenario of aquatic organisms in Macaronesia. In: Abstracts 1st Symp. "Fauna and flora of the Atlantic islands", Oct. 4-9, 1993: 62 (Museu Municipal do Funchal \& Delegação Regional da Madeira da Associação Portuguesa de biólogos, Funchal, Madeira).

Stock, J.H. Copepoda (Crustacea) associated with commercial and non-commercial Bivalvia in the East Scheldt, The Netherlands. Bijdr. Dierk., 63: 61-64.

Stock, J.H. How endangered is Gammarus duebeni celticus, a native freshwater amphipod in western Brittany (France). Arch. Hydrobiol., 128: 415-421.

Stock, J.H. Pycnogonida: Description d'Ascorhynchus miniscapus sp. nov,, récolté sur le banc de la Bayonnaise (nord-ouest des îles Wallis et Futuna). Résultats des Campagnes MUSORSTOM, 11. Mém. Mus. natn. Hist. nat, (A) 158: 349-353.

Stock, J.H. Some remarkable distribution patterns in stygobiont Amphipoda. J. nat. History, 27: 807-819.

Stock, J.H. Review of F. Cervigón et al., 1992. Guia de campo de las especies comerciales marinas y de aguas salobres de la costa septentrional de Sur America. Crustaceana, 64: 127

Stock, J.H. Review of Adrian Wenner \& Armand Kruis, eds., Crustacean egg production. Crustaceana, 64: 127

Stock, J.H. \& A.D. Abreu. Talitridae (Crustacea, Amphipoda) from non-marine habitats in Madeira. Boletim Mus. munic. Funchal, 44 (240) "1992": 115-129.

Stock, J.H. \& A.D. Abreu. Three new species of Pseudoniphargus (Crustacea: Amphipoda) from the Madeira Archipelago. Boletim Mus. munic. Funchal, 44 "1992": 131155 .

\section{4}

Stock, J.H. Biogeographic synthesis of the insular groundwater faunas of the (sub)tropical Atlantic. Hydrobiologia, 28: 105-117.

Stock, J.H. Indo-West Pacific Pycnogonida collected by some major oceanographic expeditions. Beaufortia, 44: 17-78.

Stock, J.H. Shifting ranges and biodiversity in animal ecosystems. In: O.T. Solbrig, H.M. van Emden \& P.G.W.J. van Oordt (eds.), Biodiversity and global change.' Int. Union biol. Sci., Monogr. 8: 169-173.

Stock, J.H. De "slijkgarnaal" Corophium sextonae (Amphi- 
poda) plotseling talrijk in de Oosterschelde. Het Zeepaard, 54: 82-84.

Stock, J.H. \& C.K. Biernbaum. Terrestrial Amphipoda (Talitridae) from Ascension and Saint-Helena (south central Atlantic). J. nat. Hist., 28: 795-811.

Beyer, G. \& J.H. Stock. Epigean freshwater Gammaridae (Crustacea, Amphipoda) from La Gomera (Canary Islands). Bijdr. Dierk., 64: 101-114.

\section{5}

Stock, J.H. Copepoda Poecilostomatoida associated with Bivalvia from New Guinea. Hydrobiologia, 312: 37-45.

Stock, J.H. De eerste vondsten van het zeepokken-geslacht Chthamalus in Nederland. Het Zeepaard, 55: 119-123.

Stock, J.H. Gammarus and Chaetogammarus (Crustacea, Amphipoda) from Macaronesia. Boletim Mus. munic. Funchal, 45: 41-52.

Stock, J.H. The genus Sarothrogammarus Martynov, 1935 (Crustacea, Amphipoda) in Madeira. Boletim Mus. munic. Funchal, 45: 29-40.

Stock, J.H. De glasvlooien (Amphipoda, geslacht Hyale) van Nederland. Het Zeepaard, 55: 46-47.

Stock, J.H. A new member of the family Bogidiellidae (Crustacea, Amphipoda) from poikilohaline waters of Madeira. Bocagiana, 171: 1-8.

Stock, J.H. Orchestia aestuarensis (Amphipoda, Talitridae) nu ook in Nederland aangetroffen. Het Zeepaard, 55: 8184.

Stock, J.H. Origin and evolution of the island of SaintHelena (South Atlantic). List of sampling stations AprilMay 1995. Versl. techn. Gegevens zoöl. Mus. Univ. Amsterdam, 63: 1-9.

Stock, J.H. Two new copepods parasitic on Caribbean polychaetes. Stud. nat. Hist. Caribb. Region, 72: 1-11.

Stock, J.H. Two new poecilostomatoid copepods (Crustacea) associated with the polychaete Spirobranchus from the Seychelles. J. Afr. Zool., 209: 77-88.

Stock, J.H. Vindplaatsen van de Ivoorpok, Balanus eburneus, in Nederland. Het Zeepaard, 55: 19-22.

Stock, J.H. [Announcement] Good news about the Mediterranean Amphipoda. Crustaceana, 68: 918.

Stock, J.H. [Review of] T. Gledhill, D.W.Sutcliffe \& W.D. Williams, 1993. British freshwater Crustacea: Malacostraca. Crustaceana, 68: 533.

Stock, J.H. [Review of] V. Gotto, 1993. Commensal and parasitic copepods associated with marine invertebrates (and whales). Crustaceana, 68: 532.

J.H. Stock, [Review of] Z. Kabata, 1993. Copepods parasitic on fishes. Crustaceana, 68: 532.

J.H. Stock, [Review of] S. Ruffo (ed.), 1993. The Amphipoda of the Mediterranean, part 3. Crustaceana, 68: 533.

Stock, J.H. \& A. Humes. Copepoda associated with Echi- noidea from the West Indies. Stad, nat. Hist. Caribb. Region, 72: 25-46.

Stock J.H. \& T.M. Iliffe. Melitidae (Crustacea, Amphipoda) from anchihaline limestone caves in New Caledonia. Contr. Zool, 65: 245-269.

Miyazaki, K. \& J.H. Stock. Rhynchothorax mediterraneus, the first record of Rhynchothoracidae (Pycnogonida) from Japan. Publs. Seto mar. biol, Lab., 36: 325-327.

\section{6}

Stock, J.H. Age of limnic and stygobiont Amphipoda of the Madeira Archipelago and La Gomera, Canary Islands. Polskie Archiwum Hydrobiologii, 42: 409-415.

Stock, J.H. Biogeography and evolutionary scenario of aquatic organisms in Macaronesia. Boletim Mus. munic. Funchal, Suppl. 4 "1995": 729-745.

Stock, J.H. The genus Platorchestia (Crustacea, Amphipoda) on the Mid-Atlantic islands, with description of a new species from Saint-Helena. Miscel. zool., 19: 149-157.

Stock, J. In Memoriam Sjouke Pinkster. ISP [Institute for Systematics and Population Biology, University of Amsterdam] Berichten, 26: 20-22.

Stock, J.H. Sabelliphilus elongatus, een parasitaire Copepode van de kokerworm Sabella, in de Oosterschelde. Het Zeepaard, 56: 14-15.

Stock, J. H. Two new species of Copepoda parasitic on polynoid polychaetes. Crustaceana, 69: 438-445.

Stock, J.H. \& J.C. von Vaupel Klein. Mounting media revisited: the suitability of Reyne's fluid for small Crustaceans. Crustaceana, 69: 793-798,

Kim, Il-Hoi \& J.H. Stock. A new species of Clausidiidae (Copepoda, Poecilostomatoida) associated with the bivalve Ruditapes philippinarum in Korea. Cah. Biol, mar., 37: 1-6.

1997

Stock, J.H. A new species of Brevitalitrus (Crustacea, Amphipoda, Talitridae) from Mauritius - first record of the genus from the Indian Ocean. Revue suisse Zool., 104: 3-11

Stock, J.H., J.J. Vermeulen \& A. Mutey Al Nofli. Research program: Biological ground water survey of the Sultanate of Oman - List of sampling stations March-April 1996. Versl, techn. Gegevens Inst. Syst. Pop. Biol. (Zoöl. Mus.) Univ. Amsterdam, 71: 1-15.

Botosaneanu, L. \& J.H. Stock. Stygofauna of Oman, 1. A new freshwater stygobiont Cyathura (Isopoda, Anthuridae), from interstitia of coarse wadi sediments in Oman. Annls. Límnol., 33: 97-84.

Received: 30 June 1997 